\title{
Pengembangan lembar kegiatan siswa (LKS) berbasis penemuan terbimbing pada materi perbandingan trigonometri pada segitiga siku-siku kelas X SMA Islam
}

\author{
Nita Mahdiana, M. Shohibul Kahfi* \\ Universitas Negeri Malang, Jl. Semarang No. 5 Malang, Jawa Timur, Indonesia \\ *Penulis korespondensi, Surel: muhammad.shohibul.fmipa@um.ac.id
}

Paper received: 01-09-2021; revised: 15-09-2021; accepted: 30-08-2021

\begin{abstract}
The research was aimed to develop and to know the feasibility student's worksheet based on guided discovery learning on trigonometric ratio on a right triangle for tenth grade of Islamic Senior High School Kepanjen. The development model oriented to the Plomp (2013) development model which consists of three stages: preliminary research, prototyping phase, assesment phase. The results showed that student's worksheet was declared valid with a validity student's worksheet was 3.21 , the validity score of the student response questionnaire was 3.16, the validity score of observation sheet of student activities was 3.50 and the validity score of test was 3.33. The student worksheets also meet the practical criteria based on the results of students questionnaire with the practicability score that is 3.17 and observation sheet of student activities with the practicability score that is 3.78. The student's worksheet developed also fulfills the effective criteria with a percentage of 81.81 percent of students getting a score above the KKM. Thus, the developed worksheet was feasible tu use because meets the criteria of valid, practical, and effective.
\end{abstract}

Keywords: Student's worksheet; guided discovery; perimeter and area of rectangles.

\begin{abstract}
Abstrak
Penelitian ini bertujuan untuk mengembangkan dan mengetahui kelayakan LKS berbasis penemuan terbimbing pada materi perbandingan trigonometri pada segitiga siku-siku kelas X SMA Islam Kepanjen. Model pengembangan mengacu pada model pengembangan Plomp (2013) yang terdiri dari 3 tahap: preliminary research, prototyping phase, dan assesment phase. Hasil penelitian menunjukkan bahwa LKS dinyatakan valid dengan skor kevalidan LKS 3,21, skor kevalidan angket respon siswa 3,16, skor kevalidan lembar observasi kegiatan siswa 3,50 dan skor kevalidan soal tes 3,33. LKS juga memenuhi kriteria praktis berdasarkan hasil angket respon siswa dengan skor kepraktisan 3,17 dan lembar observasi kegiatan siswa dengan skor kepraktisan 3,78. LKS yang dikembangkan juga memenuhi kriteria efektif dengan presentase 81,81 persen siswa mendapat nilai di atas KKM. Dengan demikian, LKS yang dikembangkan layak untuk digunakan karena memenuhi kriteria valid, praktis, dan efektif.
\end{abstract}

Kata kunci: Lembar Kegiatan Siswa (LKS); penemuan terbimbing; perbandingan trigonometri pada segitiga siku-siku.

\section{Pendahuluan}

Pembelajaran merupakan suatu proses atau kegiatan yang sistematis dan sistemik yang bersifat interaktif dan komunikatif antara pendidik dengan siswa, sumber belajar, dan lingkungan untuk menciptakan kondisi yang memungkinkan terjadinya tindakan belajar siswa (Arifin, 2010). Salah satu faktor penting dalam proses pembelajaran adalah sarana dan prasarana. Sarana adalah segala sesuatu yang mendukung secara langsung terhadap kelancaran proses pembelajaran, sedangkan prasarana adalah segala sesuatu yang secara tidak langsung dapat mendukung keberhasilan proses pembelajaran (Sanjaya, 2008). Sarana dan prasarana yang lengkap dapat membantu guru dalam penyelenggaraan proses 
pembelajaran, dengan demikian sarana dan prasarana merupakan komponen penting yang dapat mempengaruhi proses pembelajaran.

Bahan ajar adalah segala bentuk bahan yang digunakan untuk membantu guru dalam melaksanakan kegiatan pembelajaran. Bahan yang dimaksud bisa berupa bahan tertulis maupun bahan tidak tertulis (Depdiknas, 2008). Melalui bahan ajar, siswa dapat mempelajari suatu kompetensi secara runtut dan sistematis sehingga diharapkan siswa akan mampu menguasai semua kompetensi secara utuh.Bahan ajar dapat diimplementasikan pada semua mata pelajaran, salah satunya adalah mata pelajaran matematika.

Salah satu topik dalam pelajaran matematika yang dipelajari di SMA adalah trigonometri (permendikbud, 2013). Trigonometri dianggap sebagai salah satu materi matematika yang sulit karena banyaknya rumus yang harus dihafalkan, kesulitan dalam menggunakan rumus karena bentuk rumus yang hampir sama, dan kesulitan dalam menguraikan soal yang diberikan. Siswa mulai dikenalkan dengan materi trigonometri pada kelas X. Kesulitan memahami materi trigonometri juga dialami siswa di SMA Islam Kepanjen. Hal ini disimpulkan dari hasil wawancara secara tidak terstruktur pada tanggal 24 Oktober 2018 dengan salah satu guru matematika yang mengajar kelas X di SMA Islam Kepanjen. Beberapa pertanyaan yang peneliti tanyakan antara lain apakah trigonometri merupakan materi yang sulit bagi siswa, bagaimana hasil belajar siswa pada materi trigonometri, dan mengapa siswa sulit dalam mempelajari trigonometri. Berdasarkan hasil wawancara diperoleh bahwa trigonometri merupakan materi yang dianggap sulit bagi siswa karena merupakan materi baru yang belum pernah dipelajari sebelumnya sehingga siswa masih merasa asing, selain itu masih banyak siswa yang hasil ulangannya masih kurang memuaskan pada materi trigonometri dan beberapa kesulitan siswa dalam mempelajari trigonometri diantaranya siswa masih merasa kesulitan dalam menguraikan soal yang diberikan.

Beberapa faktor yang menyebabkan siswa mengalami kesulitan dalam mempelajari trigonometri diantaranya siswa masih mengalami kesulitan dalam memahami materi trigonometri yang terdapat pada bahan ajar yang digunakan. Bahan ajar yang dibagikan kepada siswa cenderung memberikan rumus secara langsung sehingga siswa lebih senang menghafalkan rumus daripada memahami proses mendapatkan rumus tersebut. Berdasarkan faktor kesulitan siswa tersebut, salah satu bahan ajar yang dapat menunjang pembelajaran di kelas adalah Lembar Kegiatan Siswa (LKS).

LKS merupakan salah satu bahan ajar yang dapat dijadikan pedoman bagi guru dan siswa untuk mempermudah pembelajaran. Menurut Depdiknas (2008) Lembar Kegiatan Siswa (LKS) merupakan lembaran-lembaran berisikan tugas serta petunjuk atau langkahlangkah kegiatan dalam melakukan pembelajaran yang harus dikerjakan oleh siswa dan mengacu pada kompetensi dasar yang akan dicapai. Suatu tugas yang terdapat pada Lembar Kegiatan Siswa (LKS) harus jelas kompetensi dasar yang akan dicapainya.Mengajar dengan menggunakan LKS dalam proses belajar mengajar memberikan beberapa manfaat, antara lain memudahkan guru dalam mengelola proses belajar mengajar, misalnya dalam mengubah kondisi belajar yang semula berpusat pada guru (teacher centered) menjadi berpusat pada siswa (student centered) (Darmojo \& Kaligis,1991). 
Pada pembelajaran kurikulum 2013, siswa dituntut untuk aktif dalam proses pembelajaran, sedangkan guru hanya berperan sebagai fasilitator. Akan tetapi, berdasarkan hasil observasi berupa wawancara dengan guru matematika di SMA Islam Kepanjen menunjukkan bahwa pembelajaran matematika masih menggunakan metode ceramah dan latihan soal. Metode ceramah merupakan metode konvensional yang dapat menjadikan siswa pasif saat kegiatan pembelajaran karena siswa hanya mendengarkan penjelasan guru. Hal ini bertolak belakang dengan kurikulum 2013 yang dikembangkan dengan beberapa penyempurnaan pola pikir diantaranya yaitu pola pembelajaran yang berpusat pada guru menjadi pembelajaran berpusat pada siswa, pola pembelajaran satu arah menjadi pola pembelajaran interaktif, pola pembalajaran pasif menjadi pola pembelajaran aktif mencari tahu (Lampiran Peraturan Menteri Pendidikan dan Kebudayaan Nomor 68 Tahun 2013 tentang Kerangka Dasar dan Struktur Kurikulum Sekolah Menengah Pertama). Selain hal tersebut, bahan ajar yang dibagikan kepada siswa memang belum membuat siswa aktif dan mandiri dalam belajar. Kondisi tersebut menyebabkan pembelajaran didominasi oleh peran aktif guru. Oleh karena itu, dalam pengembangan Lembar Kegiatan Siswa (LKS) dibutuhkan suatu metode supaya LKS tersebut dapat dipahami dengan mudah dan siswa menjadi lebih aktif serta lebih mandiri dalam proses pembelajaran. Berdasarkan hal tersebut LKS maka peneliti memilih untuk mengembangkan LKS berbasis penemuan terbimbing.

Pengertian discovery learning menurut Jerome Bruner (1961) adalah metode pembelajaran yang menggunakan teori pembelajaran konstruktivisme berbasis inkuiri yang terjadi dalam situasi pemecahan masalah dimana siswa belajar melalui pengetahuan yang ada dan pengalaman sebelumnya untuk menemukan fakta dan hubungan dengan materi baru yang sedang dipelajari. Hal yang mendasari ide J. Bruner adalah pendapat dari piaget yang menyatakan bahwa anak harus berperan secara aktif dalam proses pembelajaran di kelas. Untuk itu Bruner menggunakan suatu metode yang disebut discovery learning atau penemuan terbimbing, yaitu dimana siswa mengorganisasikan bahan yang dipelajari dengan suatu bentuk akhir.

Metode penemuan terbimbing dapat mengaktifkan siswa selama proses pembelajaran, karena siswa dibimbing dan melakukan kegiatan penemuan secara mandiri untuk menemukan suatu konsep. Selain itu, dengan melakukan kegiatan penemuan siswa akan mampu memahami materi pembelajaran karena siswa mengalami sendiri proses menemukannya sehingga siswa dapat lebih lama mengingat. Siswa akan merasa puas ketika menemukan sendiri, kepuasan tersebut mendorong siswa ingin melakukan penemuan lagi sehingga minat belajarnya meningkat. Jika siswa terlibat aktif dalam menemukan suatu konsep matematika, maka daya ingat siswa akan lebih lama dan siswa mampu mengaplikasikannya jika menemukan permasalahan yang berbeda (Trianto, 2010).

Berdasarkan paparan uraiang di atas, penting dilakukan pengembangan Lembar Kegiatan Siswa (LKS) berbasis penemuan terbimbing pada materi perbandingan trigonometri pada segitiga siku-siku kelas X SMA Islam Kepanjen.

\section{Metode}

Penelitian ini termasuk jenis penelitian pengembangan. Model pengembangan yang digunakan dalam pengembangan Lembar Kegiatan Siswa (LKS) berbasis penemuan terbimbing yaitu model pengembangan Plomp (2013). Model pengembangan ini terdiri dari 
tiga fase yaitu preliminary research (penelitian awal), prototyping phase (tahap pengembangan), dan assesment phase (tahap penilaian).

Penelitian awal dilakukan dengan menganalisis kebutuhan dan konteks, melakukan tinjauan literature, mengembangkan kerangka konseptual atau teoritis untuk penelitian (Plomp, 2013: 19). Penelitian awal dilakukan untuk mengidentifikasi kebutuhan yang diperlukan untuk mengatasi permasalahan dalam kegiatan pembelajaran.

Analisis kebutuhan dilakukan melalui wawancara dengan siswa kelas X dan XI SMA Islam Kepanjen untuk memperoleh informasi tentang kesulitan siswa dalam belajar materi trigonometri, metode pembelajaran yang digunakan oleh guru, bahan ajar yang digunakan, dan kondisi pembelajaran saat menggunakan bahan ajar yang tersedia. Selanjutnya peneliti melakukan kajian terkait metode pembelajaran yang sesuai untuk materi trigonometri dengan meninjau dari beberapa referensi. Berdasarkan beberapa referensi tersebut, peneliti memperoleh informasi bahwa metode penemuan terbimbing dapat membimbing siswa untuk menemukan konsep dan langkah-langkah penemuannya dilakukan oleh siswa. Dalam metode tersebut, siswa akan lebih aktif dalam proses pembelajaran serta dapat memahami konsep secara mandiri.

Pada tahap tahap prototyping phase (tahap pengembangan) dilakukan desain solusi dari permasalahan pada tahap penelitian awal berupa pengembangan produk yang dapat mengaktifkan siswa serta membantu dalam mengkonstruk konsep perbandingan trigonometri pada segitiga siku-siku. Produk yang dihasilkan pada tahap ini adalah LKS yang dikembangkan sesuai dengan langkah-langkah metode pembelajaran penemuan terbimbing. LKS yang dikembangkang terdiri dari 3 LKS. LKS 1 berisi langkah-langkah untuk menemukan konsep perbandingan trigonometri pada segitiga siku-siku dan nilai perbandingan trigonometri pada segitiga siku-siku untuk sudut-sudut istimewa. LKS 2 berisi langkahlangkah untuk menentukan hubungan antar perbandingan trigonometri. LKS 3 berisi tentang cara menentukan perbandingan trigonometri apabilan diketahui perbandingan trigonometri yang lain. LKS dibuat dengan berpedoman pada struktur LKS berdasarkan Pedoman Pengembangan Bahan Ajar (Depdiknas, 2008). Produk yang dihasilkan selanjutnya yaitu tes tulis, dan instrumen penelitian sebagai alat untuk melakukan evaluasi terhadap kualitas LKS yang dikembangkan.

Tahap asesmen merupakan tahap evaluasi untuk menyimpulkan apakah solusi atau intervensi memenuhi spesifikasi yang telah ditentukan sebelumnya (Plomp, 2013: 19). Tahap ini bertujuan untuk mengetahui kevalidan, kepraktisan, dan keefektifan bahan ajar yang dikembangkan. Pada tahap ini juga dilakukan uji coba lapangan sebagai uji kepraktisan dan keefektifan produk.

Pada tahap ini dilakukan kegiatan validasi yang dilakukan oleh validator yaitu satu dosen matematika Universitas Negeri Malang. Validator diminta untuk mengevaluasi perangkat pembelajaran dari segi konten dan pembelajaran. Evaluasi dilakukan dengan instrument berupa lembar validasi, kemudian hasil validasi akan digunakan untuk merevisi dan menyempurnakan produk yang dikembangkan. Pada tahap ini juga dilakukan uji coba lapangan sebagai uji kepraktisan dan keefektifan produk. Instrumen penilaian kepraktisan produk yang dikembangkan adalah lembar observasi kegiatan siswa dan angket respon 
siswa, sedangkan instrumen penilaian keefektifan produk yang dikembangkan adalah hasil tes tulis dari subjek uji coba. Perangkat dikatakan valid, praktis, dan efektif apabila memenuhi kriteria valid, praktis, dan efektif.

Penelitian ini dilaksanakan di SMA Islam Kepanjen dengan subjek uji coba yaitu seluruh siswa kelas X IPA 1 SMA Islam Kepanjen yang berjumlah 22 siswa, yang belum mempelajari materi perbandingan trigonometri pada segitiga siku-siku dengan kemampuan siswa yang heterogen. Data yang diperoleh dari uji coba yaitu data kualitatif yang diperoleh dari hasil validasi yang berupa saran dan komentar/perbaikan yang diberikan oleh validator ahli dan validator praktisi pada lembar validasi, saran dan komentar yang diberikan oleh siswa pada angket respon siswa dan, saran dan komentar yang diberikan oleh observer pada lembar observasi kegiatan siswa. Sedangkan data kuantitatif berupa skor penilaian yang diberikan oleh validator ahli dan validator praktisi pada lembar validasi, skor hasil angket respon siswa, skor hasil lembar observasi kegiatan siswa dan skor siswa dalam tes hasil belajar. Data kuantitatif dianalisis berdasarkan teknik analisis data kuantitatif yang diadaptasi dari Hobri (2010).

\section{Hasil dan Pembahasan}

\subsection{Hasil}

Data hasil uji kevalidan diperoleh dari hasil validasi satu dosen jurusan matematika sebagai validator ahli dan satu guru matematika kelas X SMA Islam Kepanjen yang sedang mengampu materi perbandingan trigonometri pada segitiga siku-siku sebagai validator praktisi. Lembar yang akan divalidasi terdiri dari lembar validasi LKS, lembar validasi angket respon siswa, lembar validasi lembar observasi kegiatan siswa, dan lembar validasi soal tes. Data yang diperoleh terdiri dari data kuantitatif dan data kualitatif. Data kuantitatif berupa skor penilaian pada masing-masing indikator dan data kualitatif berupa komentar/perbaikan dari validator.

Hasil skor rata-rata lembar validasi LKS yang diisi oleh validator ahli dan validator praktisi adalah 3,21 dengan kriteria valid. Komentar atau saran yang diberikan validator terhadap LKS yang dikembangkan yaitu pada cover LKS ditambahkan nama pembuat dan kolom identitas siswa, perlu ditambahkan kompetensi inti dan ditambahkan nomor halaman pada LKS yang dikembangkan.

skor rata-rata lembar angket respon siswa yang diisi oleh oleh validator ahli dan validator praktisi adalah 3,16. Komentar atau saran yang diberikan validator terhadap lembar angket respon siswa yaitu redaksi kalimat pada petunjuk nomor 2 perlu diganti. Hasil skor rata-rata lembar validasi lembar observasi kegiatan siswa yang diisi oleh validator ahli dan validator praktisi adalah 3,50 dengan kriteria valid. Hasil skor rata-rata lembar validasi soal tes yang diisi oleh validator ahli dan validator praktisi adalah 3,33 dengan kriteria valid. Komentar atau saran yang diberikan validator terhadap lembar soal tes yaitu lembar soal dan lembar jawaban sebaiknya dijadikan satu dan pada soal nomor 1 perlu ditunjukkan bahwa segitiga yang dimaksud adalah segitiga siku-siku.

Data hasil uji kepraktisan LKS diketahui berdasarkan lembar angket respon siswa dan lembar observasi kegiatan siswa. Hasil skor pengisian angket oleh seluruh siswa yaitu 3,17. Hal ini menunjukkan bahwa LKS yang dikembangkan memenuhi kriteria praktis. Sementara itu, hasil skor pengisian lembar observasi kegiatan siswa yang dilakukan oleh 
observer memperoleh skor 3,78. Hal ini menunjukkan bahwa LKS yang dikembangkan memenuhi kriteria praktis. Selanjutnya, hasil uji keefektifan LKS diketahui berdasarkan hasil tes siswa setelah mengerjakan produk LKS yang dikembangkan. Hasil tes menunjukkan 81,81\% siswa mendapat nilai di atas KKM yang ditetapkan yaitu 75 .

\subsection{Pembahahasan}

Hasil analisis data yang diperoleh dari uji kevalidan, uji kepraktisan, dan uji keefektifan menunjukkan bahwa LKS yang dikembangkan memenuhi kriteria valid, praktis, dan efektif. Sehingga, LKS layak digunakan untuk siswa kelas X SMA dalam pembelajaran matematika khususnya pada materi perbandingan trigonometri pada segitiga siku-siku. LKS berbasis penemuan terbimbing yang dikembangkan dapat mengubah pembelajaran menjadi berpusat pada siswa dan dapat mengaktifkan siswa dalam menemukan konsep. Pada pembelajaran menggunakan LKS yang dikembangkan, siswa terlibat langsung dalam penemuan suatu konsep, siswa tidak hanya menghafal materi.

LKS yang dikembangkan disusun berdasarkan tahapan pada pembelajaran penemuan terbimbing. Pada tahap stimulasi/pemberian rangsangan siswa diminta untuk membaca serta mengamati uraian permasalahan yang terdapat pada LKS serta beberapa pertanyaan terkait permasalahan tersebut. Pada tahap pernyataan/identifikasi masalah siswa di beri kesempatan untuk mengidentifikasi masalah yang revelan dengan bahan pembelajaran. Pada LKS yang dikembangkan ini, siswa diminta untuk mengajukan pertanyaan berdasarkan permasalahan yang telah diuraikan sebelumnya. Tahap pengumpulan data yaitu siswa diberi kebebasan untuk mengumpulkan informasi-informasi dengan mengisi pertanyaan panduan yang terdapat pada LKS. Tahap pengolahan data yaitu siswa diberi kesempatan untuk mendiskusikan pertanyaan dengan mengaitkan informasi yang telah diperoleh pada tahap pengumpulan data. Tahap verifikasi yaitu menyelesaikan permasalahan dari tahap stimulasi. Tahap generalisasi yaitu menyimpulkan dari seluruh kegiatan pada LKS berupa rumus konsep perbandingan trigonometri pada segitiga siku-siku. Bagian kesimpulan pada LKS yang dikembangkan ini bertujuan untuk mengemas materi pembelajaran yang diperoleh dan memperkuat pemahaman siswa. Selain itu, pada LKS juga terdapat soal latihan untuk menerapkan rumus yang telah ditemukan.

LKS yang telah dikembangkan terdiri dari 3 LKS yang digunakan untuk 2 kali pertemuan. LKS 1 berisi tentang perbandingan trigonometri (sin, cos, tan, coses, secan, cotan) pada segitiga siku-siku. Melalaui LKS ini siswa di bimbing untuk konsep perbandingan trigonometri (sin, cos, tan, coses, secan, cotan) pada segitiga siku-siku dan nilai perbandingan trigonometri pada sudut-sudut istimewa. LKS 2 berisi tentang hubungan antara sin $a$ dengan $\operatorname{cosec} a, \cos a$ dengan $\sec a, \tan a$ dengan $\operatorname{cotan} a$ dan hubungan antara tan $a$ dengan $\sin a$ dan $\cos a$. Melalaui LKS ini, siswa dibimbing untuk menemukan hubungan antara $\sin a$ dengan $\operatorname{cosec} a, \cos a$ dengan $\sec a, \tan a$ dengan $\operatorname{cotan} a$ dan hubungan antara tan $a$ dengan $\sin a$ dan $\cos a$. LKS 3 berisi tentang menentukan perbandingan trigonometri apabila diketahui perbandingan trigonometri yang lain. Melalui LKS ini, siswa dibimbing menentukan suatu perbandingan trigonometri apabila diketahui perbandingan trigonometri yang lain.

Lembar Kegiatan Siswa (LKS) yang dikembangkan mempunyai kelebihan dan kekurangan. Kelebihan dari LKS yang dikembangkan yaitu a) LKS yang dikembangkan menuntut siswa untuk menemukan konsep perbandingan trigonometri pada segitiga siku- 
siku melalui pertanyaan-pertanyaan yang membimbing pada LKS. Melalui penemuan, siswa dapat mengingat lebih lama rumus tersebut dari pada hanya sekedar menghafal, b) LKS yang dikembangkan dirancang agar siswa dapat memahami konsep perbandingan trigonometri pada segitiga siku-siku. Hal tersebut dapat dilihat berdasarkan hasil evaluasi siswa setelah menggunakan LKS yang dikembangkan yakni menunjukkan bahwa 81,81\% siswa memperoleh nilai di atas KKM yaitu 75, c) LKS yang dikembangkan didesain menarik, sehingga siswa merasa senang dan bersemangat mempelajari materi perbandingan trigonometri pada segitiga siku-siku menggunakan LKS yang dikembangkan. Hal tersebut dapat dilihat pada hasil kepraktisan angket respon siswa yang memperoleh skor rata-rata 3,20 yang menyatakan tampilan LKS menarik, d) LKS yang dikembangakn menyajikan masalah kontekstual yang berkaitan dengan materi oerbandingan trigonometri pada segitiga siku-siku. Hal tersebut membuat siswa aktif dalam diskusi karena siswa diberikan fenomena dalam kehidupan nyata untuk didiskusikan dalam kelompok, dan e) LKS yang dikembangkan dapat meningkatkan keaktifan siswa dalam pembelajaran, karena LKS dikerjakan dan didiskusikan secara berkelompok. Selain itu, pada lembar observasi kegiatan siswa, observer juga menyatakan bahwa siswa aktif pada kegiatan diskusi kelompok. Selain kelebihan, LKS berbasis penemuan terbimbing yang dikembangkan juga memiliki beberapa kekurangan yaitu a) LKS yang dikembangkan menyediakan sedikit latihan soal, karena LKS hanya terfokus pada menemukan konsep perbandingan trigonometri pada segitiga siku-siku, b) permasalahan yang terdapat pada LKS 1 membuat siswa mengalami sedikit kebingungan, dan c) masih terdapat beberapa kesalahan penulisan kata dalam LKS yang dikembangkan.

\section{Simpulan}

\subsection{Kesimpulan}

Berdasarkan uji kevalidan yang telah dilakukan, hasil validasi LKS memperoleh skor 3,21 dengan kriteria valid, hasil validasi angket respon siswa memperoleh skor 3,16 dengan kriteria valid, hasil validasi lembar observasi kegiatan siswa yaitu 3,50 dengan kriteria valid, dan lembar validasi soal tes yaitu 3,33 dengan kriteria valid. Setelah dinyatakan valid, produk diuji cobakan dan dinyatakan praktis. Produk dinyatakan praktis berdasarkan lembar angket respon siswa dan lembar observasi kegiatan siswa. Diperoleh skor angket respon siswa yaitu 3,17 dan lembar observasi kegiatan siswa 3,78. LKS yang dikembangkan juga memenuhi kriteria efektif, dilihat dari $81,81 \%$ siswa berhasil mendapatkan nilai di atas KKM yaitu 75 saat tes. Jadi, produk yang dikembangkan layak untuk dijadikan alternatif bahan ajar pada materi perbandingan trigonometri pada segitiga siku-siku.

\subsection{Saran}

Hasil pengembangan produk berupa LKS berbasis penemuan terbimbing diharapkan dapat memotivasi dan dapat digunakan sebagai contoh atau bahan pertimbangan dalam mengembangkan LKS berbasis penemuan terbimbing yang lebih baik lagi, selain itu produk berupa LKS berbasis penemuan terbimbing yang telah dikembangkan diharapkan dapat digunakan sebagai alternatif bahan ajar dalam pembelajaran materi perbandingan trigonometri pada segitiga siku-siku.

\section{Daftar Rujukan}

Arifin, Z. (2009). Evaluasi Pembelajaran, Bandung: PT. Remaja Rosda Karya.

Bruner, J.S. (1961). The Act of Discovery. USA : Harvard University Press. 
Darmojo, Hendro. \& Kaligis, Jenny. R. E. (1991). Pendidikan IPA II. Jakarta : Depdikbud.

Depdiknas. (2008). Panduan Pengembangan Bahan Ajar. Jakarta: Dirjen Manajemen Pendidikan Dasar dan Menengah.

Hobri. (2010). Metodologi Penelitian Pengembangan (Aplikasi pada Penelitian Penddikan Matematika). Jember: Pena Salsabila.

Mendikbud. (2013). Permendikbud Nomor 68 Tahun 2013. Tentang kerangka dasar dan struktur kurikulum sekolah menengah pertama/madrasah tsanawiyah

Permendikbud, R. I. (2015). Nomor 58 Tahun 2014 tentang Kurikulum 2013 Sekolah Menengah Pertama/Madrasah Tsanawiyah.

Plomp, T. (2013). Educational design research: An introduction. Educational design research, 11-50.

Sanjaya, Wina. (2008). Perencanaan dan Desain Sistem Pembelajaran. Jakarta: Kencana Prenada Media Group.

Trianto, T. (2010). Model pembelajaran terpadu. Jakarta: Bumi Aksara. 